

CENTRE FOR BUSINESS AND ECONOMICS RESEARCH

UNIVERSITY OF COIMBRA

\title{
Why are credit booms sometimes sweet and sometimes sour?
}

\author{
VÍTOR CASTRO \\ Loughborough University and NIPE
}

RODRIGO MARTINS

University of Coimbra and CeBER

\section{CeBER Working Papers}

No. 14

2018 


\title{
Why are credit booms sometimes sweet and sometimes sour?
}

\author{
Vítor Castro* \\ Loughborough University and NIPE \\ Rodrigo Martins \\ University of Coimbra and CeBER
}

\begin{abstract}
This paper investigates the commonalities and differences between benign credit booms and those that end up in banking crises by employing a Multinomial and a Sequential Logit model over a panel of industrial and developing countries. Some economic, political and institutional factors are found to play an important role in understanding the credit booms dynamics. In particular, this study shows that the quantity and price of credit, liquidity in the economy, economic growth, openness of the economy, government orientation, political stability and Central Bank independence are relevant to explain not only the occurrence of credit booms but also - and most importantly - whether they end up in a systemic banking crisis or not. While a better economic environment and Central Bank independence are essential for both industrial and developing countries to avoid credit booms from going badly, political factors seem to exert a stronger influence in developing countries.
\end{abstract}

Keywords: Credit booms; Multinomial Logit; Sequential Logit; Government Ideology; Central Bank Independence.

JEL classification: C25, D72, E32, E51.

\footnotetext{
* School of Business and Economics, Loughborough University, Loughborough, Leicestershire LE11 3TU, UK. Economic Policies Research Unit (NIPE), University of Minho, Campus of Gualtar, 4710-057 Braga, Portugal. Phone: +44(0) 1509 222706; E-mail: v.m.q.castro@lboro.ac.uk

^ Faculty of Economics, University of Coimbra, Av. Dias da Silva 165, 3004-512 Coimbra, Portugal. Centre for Business and Economics Research (CeBER), Av. Dias da Silva 165, 3004-512 Coimbra, Portugal. Tel.: +351239790543; Fax: +351239790514; E-mail: rodrigom@fe.uc.pt
} 


\section{Introduction}

Credit is beneficial to the economy as it helps to support investment and economic growth. But when credit grows too fast financing ends up being extended to riskier investment projects with lower net present value, frauds are more likely to occur and the overall quality of the projects that are backed up drops. This means that during credit crunches banks may become highly vulnerable, which can trigger systemic banking crises. According to our data, approximately 1 out of 4 credit booms end up this way. Hence, it is important to understand how to mitigate this tradeoff between positive and negative aftermaths by distinguishing credit booms before they fully unfold.

This has been an important investigation topic in recent years. However, researchers have found it difficult to predict credit booms that end up in a systemic banking crisis ("bad" credit booms) and soft landings ("good" credit booms); they have also struggled to understand their fundamental differences. The literature has provided some mixed results and, in reality, the only identifiers that have been consistently associated with "bad" credit booms are larger magnitudes and longer durations (see Gourinchas et al. 2001; Barajas, et al. 2009; Arena et al. 2015; Dell'Ariccia et al., 2016). Most studies rely on binary choice probit/logit models where the dependent variable is typically a dummy that accounts for periods of abnormal credit growth that

end up in a banking crisis. With such econometric approach, those studies have neglected the fact that we have indeed three outcomes in this dynamics: "good", "bad", and no credit boom. Hence, a Multinomial Logit would be a better fit to this particular analysis. Alternatively, these three events can be treated as a sequence of stages: in a first stage, we have the possibility of a credit boom occurring or not; in a second stage - if a credit boom occurs - it can be distinguished between 
"bad" or "good". This means that a sequential logit model would be a more suitable econometric approach to explore this dynamics.

As a first contribution of this paper, we revisit the study of the drivers of "good" and "bad" credit booms by relying on these more adequate econometric techniques and on an extensive quarterly dataset for a panel of industrial and developing countries. Additionally, this paper provides some other significant contributions to the existing literature by going beyond the traditional economic framework and exploring the role of political aspects and of Central Bank Independence, factors that to date have not been accounted for yet.

Regarding the political determinants, there are reasons to assume that such environmental aspects can indeed affect credit booms dynamic since there is ample evidence suggesting that features like the electoral agenda, government ideology and political stability impact the overall macroeconomic performance - this linkage is developed further ahead in the text. As to the role that Central Banks can play in this process, we assume that since more independent Central Banks are less susceptible to political pressures based on popularity concerns, they are better equipped to intervene during credit expansions. This raises a particularly interesting question: Do more independent Central Banks actually affect the likelihood of a "bad" credit boom? Our results provide an affirmative answer by showing that "bad" credit booms are indeed less likely to occur under the watch of more independent Central Banks. A similar effect is found when right-wing parties are in office.

Finally, contrary to most studies, that tend to struggle in finding significant macroeconomic differences between innocuous and harmful credit expansions, our results reveal some important and robust dissimilarities between them and even between industrial and developing countries. The 
use of a richer dataset with quarterly data and suitable econometric techniques that do not disregard the periods of no credit booms are probably contributing decisively to this relevant outcome..

The rest of the paper is organized as follows. Section 2 reviews the existing literature on credit booms. Section 3 discusses the role of the political environment and of Central bank independence. Section 4 describes the data and methodology. The empirical analysis and the discussion of the results are presented in Section 5. Finally, Section 6 concludes.

\section{Literature Review}

The research on the causes of credit booms has mainly been developed from an empirical perspective and some key explanatory factors are emphasized by most of the studies in this field. ${ }^{1}$ First, credit booms have been consistently linked to sharp increases in capital inflows, usually triggered by periods of disinflation or by low interest rates in developed economies, factors that consequently raise the supply of loanable funds (Gourinchas et al., 2001; Calderón and Kubota, 2012; Gourinchas and Obstfeld, 2012). Second, these surges are also associated with a higher ratio of private credit to bank deposits which are seen to lead to financial fragility (Borio and Disyatat 2011; Gourinchas and Obstfeld, 2012). In particular, rising inflows of foreign capital may lead to excessive monetary and credit expansions (Sidaoui et al., 2011), intensify the vulnerabilities associated with currency and maturity mismatches (Akyuz, 2009), and create distortions in asset prices (Agnello and Sousa, 2013; Agnello et al., 2012). Third, productivity shocks are also seen as a phenomenon that can pressure the capital stock to increase at a higher rate than GDP, thus strongly raising the credit-to-GDP ratio. Additionally, credit expansion is more likely to occur as

\footnotetext{
${ }^{1}$ See, for example, Mendoza and Terrones, 2008, 2012; Dell'Ariccia et al., 2016. For some recent theoretical papers on the subject, see Boissay et al. (2016) and Burnside et al. (2016).
} 
the economic environment improves (Mendoza and Terrones, 2008, 2012; Meng and Gonzales, 2017). Finally, researchers point out that financial reforms associated with financial liberalization, the reduction in banks' reserve requirements and increases in the provision of financial services may also contribute to more liquidity and consequently to abnormal lending growth. ${ }^{2}$

To explain why some countries are more prone than others to credit expansions, researchers also point out to the relevance of some domestic differences. In particular, expansionary monetary and fiscal policies, less flexible exchange rate regimes and frailties in the supervision of the banking system are found to be related to the occurrence of credit booms (Elekdag and Wu 2013; Arena et al., 2015; Dell'Ariccia et al., 2016).

Banking crisis are often associated with excessive credit expansions. As such, credit plays, not just the traditional positive role of supporting investment and economic growth, but also - under certain circumstances - of harming the economy. What these circumstances are and what distinguishes "good" from "bad" episodes have been important topics of research in the literature that examines credit booms. Researchers tend to look at the aftermath of a credit expansion to reveal its nature, mainly by checking if it is followed or not by a banking crisis. Dell'Ariccia et al. (2016) point out that starting at a higher level of financial depth increases the probability of a boom ending badly. Arena et al. (2015) found that when credit booms ends in banking crisis, macroeconomic fluctuations seem to be larger and exhibit more sudden declines than in the soft landings. Meng and Gonzalez 2017 report that this is also the case when the size of the financial sector grows, especially above macroeconomic consistent levels. However, they do not find any association between "bad" booms and macroeconomic and financial policies - exception made to

\footnotetext{
${ }^{2}$ Mendoza and Terrones (2012) point that productivity surges, financial reforms, and massive capital inflow episodes appear before $20 \%$ to $50 \%$ of the peak of credit booms in industrial and emerging market economies.
} 
the quality of regulations and supervision of the banking system. Gourinchas et al. (2001) do not find any relevant differences in key macroeconomic variables between "good" and "bad" booms.

Overall, these and many other studies seem all to agree that credit booms gone badly are associated with larger magnitudes and longer durations. Nevertheless, none provides a statistical proof for these observations. One of the aims of this paper is to fill that gap in the literature by relying on adequate econometric techniques, especially in what concerns to their length and respective conditionings. Additionally, this paper also aims at extending this analysis by assessing the role of the political environment and Central Bank Independence in the dynamics of credit booms that leads to a soft landing or a banking crisis.

\section{The role of the political environment and of Central Bank independence}

In this paper, we explore the importance of the political environment and of Central Bank independence in explaining the likelihood of credit booms. Although unexplored from the econometric point of view, the relationship between politics and credit booms or financial crises has been debated in the related literature. For example, Calomiris and Haber (2014) analyse the political background of banking crises while McCarty et al. (2013) discuss how political and policy decisions in the US contributed to the housing and credit bubble that occurred in the first decade of this century; also Fernandez-Villaverde et al. (2013) examine the political dynamics of credit cycles in the Eurozone and its consequences.

There are arguments to reasonably assume that the length of credit booms might be influenced by the electoral agenda, political orientation, government support, and even political stability. Since the 1970 s numerous papers have studied the connection between politics and the economy either by highlighting the relationship between economic performance and governments' 
electoral success or by identifying politically driven policies affecting a significant number of macroeconomic variables. ${ }^{3}$

Of particular interest are the theories of "opportunistic" political business cycles suggesting that governments try to induce short-term economic expansions immediately before elections with the expectation that this may improve their chances of reelection (Nordhaus, 1975; Rogoff and Sibert, 1988; Rogoff, 1990). Conflicting with this idea we find the partisan" theory ((Hibbs, 1977; Alesina, 1987; Alesina and Sachs, 1988) which argues that governments are heterogeneous in the sense that they tend to exhibit different ideological preferences when it comes to the economy. The most emphasized difference is that left-wing governments pursue low unemployment at the cost of higher inflation, while right-wing governments prioritize low inflation at the expense of higher unemployment. Additionally, tendencies to increase taxation, to reinforce the state's intervention in the economy or to increase expenditures are considered traits more associated to left parties than with other parties.

When linking political ideology with credit expansions we believe that one of two opposing scenarios can occur. First, since right-wing governments are traditionally more prone to reduce state intervention, foster liberalization and to exert less control over the markets, one should expect them to contribute to an increase in the likelihood of a credit boom and the inverse should happen with left-wing governments. Broz (2010) shows that the expansion period of financial cycles is normally accompanied by the election of right-wing governments. Second, there are some traits generally associated with right-wing parties like a higher propensity for inflation control, smaller deficits and a lower inclination to implement income redistribution policies that may legitimize the opposite effect. The fact that the redistribution of income should be greater when left-wing governments are in power (see, for instance, Bradley et al. 2003; Iversen and Soskice, 2006) means that, under the left's rule, more people are expected to have access to credit or get involved in the

\footnotetext{
${ }^{3}$ For encompassing surveys, see Franzese (2002) and Paldam (2004).
} 
financial markets. ${ }^{4}$ This will contribute to an increase in the rate of credit expansion and the reverse should happen when right-wing parties are in office. It is important to note that those people accessing credit only because there are favourable income redistribution polices most likely are associated with a high risk of default or with lower quality of investment projects, thus potentially, increasing banks vulnerabilities. This means that right-wing governments may actually play a role in reducing the risk of bad credit booms.

Another environmental aspect to consider is that higher degrees of government neutrality and also overall political stability - like the presence of majority governments and reduced government turnover (ideological changes) - should produce a more stable economic environment, thus favoring credit growth and reducing the probability of bad credit booms occurring.

Regarding the linkage between lending growth and the electoral agenda, ample evidence is found relating policy uncertainty generated by elections and the delaying of investments, more so when the electoral race is tight (see, for example, Jens, 2017; and Canes-Wrone and Park, 2014). Thus, the disruption and uncertainty caused by elections might have a negative effect on credit expansion. As such elections may affect the likelihood of having credit booms or even their duration but there are no reasonable arguments to expect them to influence the outcome of a credit boom unless in the unlikely scenario of systematic elections in a short period of time.

From the theoretical perspective, monetary policy is also an important explanatory factor of credit booms as Central Banks are the main regulators of the quantity of money present in the system. During a credit expansion, Central Banks typically exhibit a loose monetary policy of low interest rates that makes it easier for economic agents to obtain credit which eventually leads to more and cheaper investments, thus helping credit to growth above normal levels or its fundamentals. They also play an important role in monitoring the financial system and in

\footnotetext{
${ }^{4}$ In fact, Popa (2013) shows that the size of the house price bubbles across countries is mainly related to the percentage of homeowners, with more homeowners linked to larger bubbles.
} 
preventing markets - and the overall economy - from overheating. However, political pressures exerted by governments can constrain the work of Central Banks, reducing their desired independence via three main sources. First, the Central Bank board is typically selected by the parliament or by the government directly. Chappell et al. (1993) found that this appointment process is the primary channel through which political parties can influence Central Banks. Second, governments have the ability to send monetary policy signals to the Central Bank using, for instance, media appearances to convey their preferences for a looser or tighter monetary policy (Havrilesky, 1988, 1991). Third, governments can threaten Central Bank officials, their jobs or question the very existence of the institution (Lohmann, 1998). These and other aggressive strategies may be used by politicians to force the Central Bank's policy into a particular direction.

From the governments' perspective the policy of credit expansion is definitively a good thing. More investment and higher consumption makes people happier, and happier people tend to reward the incumbent electorally. Hence, it is reasonable to assume that governments are particularly fond of periods of abnormal credit expansion and they have no desire to deal with a credit crunch. They also know that monetary policy is an important tool to create, fuel or delay the crunch of a particular credit boom. As such, it is expected that less independent Central Banks may help to increase the frequency and intensity of credit booms; moreover, they are also expected to be less prone and free to intervene when the economy displays strong signs of overinvestment, excessive risk and/or overinflated market bubbles. This means that more central bank independence is expected to decrease the probability of a credit boom ending up in a banking crisis.

\section{Data and methodology}


To investigate credit booms quarterly data was collected for 67 countries $(28$ OECD or industrial economies and 39 developing or emerging market economies) ${ }^{5}$ from 1975q1 to 2016q4. These countries were selected according to the availability of economic and political data and only include those countries or periods that exhibit regular/frequent and competitive elections.

The definition/identification of credit boom episodes is not an easy task. The literature offers some approaches but no clear consensus on the best methodology to identify them. There seems to be no right or wrong way to identify events of credit booms; each approach comes with its advantages and drawbacks (Gourinchas, et. al., 2001; Tornell and Westermann, 2002; Mendoza and Terrones, 2008, 2012; Barajas, et al., 2009; Calderón and Kubota, 2012; Dell'Ariccia et. al., 2016). To identify credit booms, we use the criteria developed by Gourinchas, et. al. (2001) - and later fine-tuned by Barajas et al. (2009) - with a threshold of $1.5 .{ }^{6}$ Hence, a credit boom (CreditBoom) is defined as an episode where the deviation of the real bank credit to the private sector, as a percentage of real GDP, from a country-specific trend in country $i$ at period $t$ (with the trend being calculated up to that period $t$ ) exceeds a determined threshold. ${ }^{7}$ In particular, a credit

${ }^{5}$ Argentina, Armenia, Australia, Austria, Belgium, Bolivia, Brazil, Bulgaria, Canada, Chile, Colombia, Costa Rica, Croatia, Cyprus, Czech Republic, Denmark, Dominican Republic, Ecuador, El Salvador, Estonia, Finland, France, Germany, Greece, Hungary, Iceland, India, Indonesia, Ireland, Israel, Italy, Japan, Kenya, Korea Republic, Latvia, Lithuania, Luxembourg, Malaysia, Malta, Mexico, Morocco, Netherlands, New Zealand, Norway, Panama, Paraguay, Peru, Philippines, Poland, Portugal, Romania, Russia, Slovak Republic, Slovenia, South Africa, Spain, Sri Lanka, Sweden, Switzerland, Taiwan, Thailand, Turkey, Ukraine, United Kingdom, United States, Uruguay, Venezuela.

${ }^{6}$ In the Appendix we provide a detailed list of the episodes of credit booms identified by this procedure and general descriptive statistics for all variables used in this study.

${ }^{7}$ The advantage of the ratio of private credit-to-GDP is that it relates private credit to the size of the economy and corrects for the pro-cyclicality in bank lending. Moreover, using this criterion makes our analysis consistent, as then we split it by the kind of boom, where we also follow Barajas et al. (2009) in the distinction between "bad" and "good" credit booms. For other procedures see, for example, Mendoza and Terrones $(2008,2012)$ and Dell'Ariccia et al. (2016). While Dell'Ariccia et al. (2016) identify boom episodes by comparing the credit-to-GDP ratio in each year $t$ and country $i$ to a backward-looking, rolling, country-specific, cubic trend estimated over the period between years $t$ - 
boom takes place if the ratio of private credit to GDP meets the following condition: the deviation of this ratio from its estimated trend is greater than 1.5 times its standard deviation or the year-onyear growth rate of private credit to GDP exceeds 20 percent. $^{8}$ According to this definition, we identify 220 episodes of credit boom episodes. The distinction between credit booms that end up in a systemic banking crisis from those that land smoothly follows Barajas et al. (2009) ${ }^{9}$. Similarly to other studies our data suggests that "bad" credit booms last more on average (11 quarters) than those that end up in a soft landing (7 quarters). ${ }^{10}$

To account for the effect of the economic environment, we rely on a set of economic variables commonly found in the related literature: total gross capital inflows as percentage of GDP (CapInflows) as proxy for capital inflows; the ratio of private credit to bank deposits (Credit/Deposits) as a proxy for the liquidity in the banking system; interest rate spread (IRspread) to account for the relative price of credit (difference between the average lending rate and the deposit rate, in percentage); growth rate of real GDP (RGDPgr); inflation rate (Inflation); current account balance as percentage of GDP (CurrAccount); trade openness (Openness) measured by exports plus imports over GDP; overvaluation of the real effective exchange rate (ApprecREER) as a proxy for asset prices (increases in the REER index means a real appreciation); exchange rate

10 and $t$, Mendoza and Terrones $(2008,2012)$ use the deviation of the real credit per capita from its long-run trend to identify those booms.

${ }^{8}$ The HP-filter is used to compute the trend, where the value of Lagrange Multiplier employed in the maximization problem is $\lambda=1600$ (for quarterly data). For robustness, we also consider later other more restrictive thresholds (1.75 and 2.0).

${ }^{9}$ The episodes of systemic banking crises are obtained from Laeven and Valencia $(2008,2010,2012)$ and updated for the more recent years following their procedure.

${ }^{10}$ Tables A1-A4 in the Appendix provide list of countries used in the estimations, credit booms date and respective duration, definition of all variables, descriptive statistics for the episodes and duration of credit booms and summary statistics for all variables used in this study. 
flexibility, proxied by the coarse classification of the exchange rate regime developed by Reinhart and Rogoff (2004), and updated by Ilzetzky, et. al. (2009) and similar sources mentioned in that paper for more recent years (ExchRateFlex). ${ }^{11}$

To account for the yet unexplored influence of the political factors, we employ a set of variables borrowed from the political business cycles and partisan literature. Some try to capture different dimensions of political instability that may affect how credit booms play out: YrBefElection and MajorityGov, dummy variables that take the value of 1 in the 4 quarters before the election, and when we are in presence of majority governments; and NGovChanges that records the number of government changes (due to elections or not) over the previous five years. Since parties from different political quadrants may have different policy agendas they wish to implement when in office, we use a government ideology dummy (Right) equal to 1 for right-wing governments ( 0 , otherwise) to account for the impact of political ideology.

Our baseline specification also accounts for the role of following institutional factors: Central Bank independence measured by the Cukierman-Webb-Neyapti weighted index and updated by Garriga (2016). As previously discussed more independent Central banks are expected to be more efficient in preventing "bad" booms; and Monetary Union $(M U)$, a dummy variable that takes the value of 1 when the country's monetary policy is in the hands of a regional monetary union.

Instead of relying on a binary distinction between periods of credit booms (1) and no credit booms (0) as other studies do, we allow for the presence of three outcomes in this dynamics: no credit boom (0); "good" credit boom (1); and "bad" credit boom. Hence, a Multinomial Logit model, as an extension of the logistic models, is the required procedure to be used in this case.

\footnotetext{
${ }^{11}$ In Table A.2 of the appendix we provide detailed information on all variables used and their respective sources.
} 
Given that now there are three categories, we set "no credit boom" as the base-category. As such, this requires the calculation of two equations, one for each category relative to the base in order to describe the relationship between the likelihood of a "good" or "bad" credit boom and the set of economic, political and institutional variables:

$$
\ln \frac{P\left(Y_{i t}=m\right)}{P\left(Y_{i t}=0\right)}=\boldsymbol{E}_{\boldsymbol{c o n}}^{\prime} \boldsymbol{\alpha}_{m}+\boldsymbol{P o l}_{i t}^{\prime} \boldsymbol{\beta}_{m}+\boldsymbol{I n s t}_{i t}^{\prime} \boldsymbol{\gamma}_{m}, \quad m=1,2
$$

Hence, for each case, there will be two predicted log odds. Computing the probabilities is a little more complicated than in the standard logistic regression. We now have,

$$
P\left(Y_{i t}=m\right)=\frac{\exp \left(\boldsymbol{E c o n}_{i t}^{\prime} \boldsymbol{\alpha}_{m}+\boldsymbol{P o l}_{i t}^{\prime} \boldsymbol{\beta}_{m}+\text { Inst }_{i t}^{\prime} \boldsymbol{\gamma}_{m}\right)}{1+\sum_{m=1}^{2} \exp \left(\boldsymbol{E c o n}_{i t}^{\prime} \boldsymbol{\alpha}_{m}+\boldsymbol{P o l}_{i t}^{\prime} \boldsymbol{\beta}_{m}+\boldsymbol{I n s t}_{i t}^{\prime} \boldsymbol{\gamma}_{m}\right)}, \quad m=0,1,2
$$

The respective log-likelihood function for $n$ individuals is the generalisation of that for the binomial logit or probit model:

$$
\ln L=\sum_{i=1}^{n} \sum_{t=1}^{T} \sum_{m=0}^{2} d_{i t m} \ln P\left(Y_{i t}=m\right), \quad m=0,1,2
$$

where $d_{i m}=1$ if outcome $m$ is observed in country $i$ at quarter $t$ and 0 otherwise.

A note on the interpretation of the parameters is now in order as, like in the standard logistic regression, the marginal effects are not the estimated coefficients. The estimated coefficient for a certain variable, $x_{k}$, correspond to the derivate of the respective log odds ratio. For example, for $\frac{P\left(Y_{i t}=2\right)}{P\left(Y_{i t}=0\right)}$, it will be $\partial \ln \frac{P\left(Y_{i t}=2\right)}{P\left(Y_{i t}=0\right)} / \partial x_{k}=\beta_{2 k}$. The marginal effect of variable $x_{k}$ on the probability of a "bad" credit boom is then given by $\frac{\partial P\left(Y_{i t}=2\right)}{\partial x_{k}}=P_{k}\left(\beta_{2 k}-\sum_{m=1}^{2} P_{m} \beta_{m k}\right)$, which is not necessarily of the same sign as the parameter involved. For the purpose of this study, we are interested in estimating both the marginal effects for each outcome and the odds ratios for the contrast between "bad" and "good" credit booms, i.e. $\partial \ln \frac{P\left(Y_{i t}=2\right)}{P\left(Y_{i t}=1\right)} / \partial x_{k}=\beta_{2 / 1, k} \cdot{ }^{12}$

\footnotetext{
${ }^{12}$ For details on this model see Greene (2012, pp. 763-766).
} 
Alternatively, these three events can be treated simultaneously as a sequence of stages: in a first stage, we have the possibility of a credit boom occurring or not; in a second stage - if a credit boom occurs - it can be distinguished between "bad" or "good". This means that a Sequential Logit model would be a more suitable econometric approach to explore this dynamics. Figure 1 describes the sequential process.

\section{Figure 1. The sequential transition process}

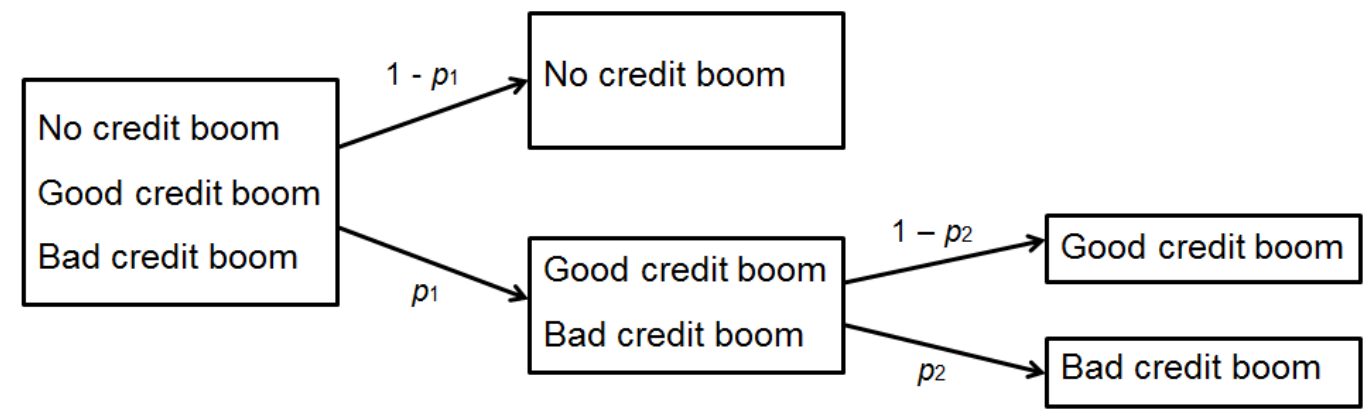

The first transition consists of a dynamics between no credit boom, on the one hand, and "good" or "bad" credit boom, on the other. The second transition consists of a dynamics between "good" and "bad" credit booms, as this path was followed in first transition. The sequential logit models the probabilities of passing these transitions. This is done by estimating a logistic regression for each transition:

$$
\begin{aligned}
& P\left(Y_{i t} \in\{\text { good, bad }\}\right)=\Lambda\left(\text { Econ }_{i t}^{\prime} \boldsymbol{\alpha}_{1}+\text { Pol }_{i t}^{\prime} \boldsymbol{\beta}_{1}+\text { Inst }_{i t}^{\prime} \boldsymbol{\gamma}_{1}\right) \\
& P\left(Y_{i t} \in\{\text { bad }\} \mid Y_{i t} \in\{\operatorname{good}, \text { bad }\}\right)=\Lambda\left(\boldsymbol{E c o n}_{i t}^{\prime} \boldsymbol{\alpha}_{2}+\boldsymbol{P o l}_{i t}^{\prime} \boldsymbol{\beta}_{2}+\text { Inst }_{i t}^{\prime} \boldsymbol{\gamma}_{2}\right)
\end{aligned}
$$

Equation (4) shows that the probability labelled $p_{1}$ in Figure 1 is related to the explanatory variables through the logistic function $\Lambda($.$) , while equation (5) shows the same for the probability labelled as$ $p_{2}$. The logistic distribution function $\Lambda($.$) is, as usual, given by \Lambda()=.\frac{\exp (.)}{1+\exp (.)}$. The coefficients on 
the regressors can be interpreted as changes in the log odds ratios, while the respective constants represent the baseline log odds of passing the first and second transitions. To interpret the results we rely on the respective odds ratios. ${ }^{13}$ This also makes them comparable with odds ratios estimated with the multinomial logit.

\section{Empirical results}

Table 1 presents the results of the Multinomial and Sequential Logit estimations. The marginal effects are reported first for the probability of each event (NoCB, GoodCB or BadCB) and then the odds-ratios for the contrast Bad versus Good credit booms. ${ }^{14}$ As the probability of no credit boom is equal to one minus the sum of the probabilities of the other two, we will focus our analysis on the results provided in columns 2 and 3; at the same time they will be compared with the respective odds-ratios estimates (column 4). The odds ratios for this contrast are also estimated employing a simple Logit model, where only events of booms are considered (column 5). The last two columns report the results (odds ratios) from the estimation of the Sequential Logit model. All economic variables are lagged one period to avoid simultaneity problems and to account for the usual delays in the reporting of economic data.

\section{[Insert Table 1 around here]}

\footnotetext{
13 For details on this model see Buis (2008, 2013). The seqlogit package developed by Buis (2013) for Stata is implemented to estimate this model. An important advantage of this estimator is that it makes it easier to test hypotheses across transitions since the entire model is estimated simultaneously and, at the same time, to compute the marginal effects for the explanatory variables on the outcome of the process for each of the sequential contrasts. This is a generalization of the multinomial logit in a ranking of multiple separate and sequential choices.

14 The factor change in the odds, usually called odds-ratio, represents generically the expected change in the odds of outcome $j$ versus outcome $l$ for a unit change in the variable $x_{k}$, and is equal to $\exp \left(\beta_{j \mid l, k}\right)$.
} 
Our findings reveal important differences between both types of booms but they also identify some commonalities. On one hand, the likelihood of "bad" credit booms is fuelled by capital inflows, higher credit-to-deposits ratio and lower interest rate spread. On the other hand, a decrease in the inflows of capital and a higher relative price of credit drive "good" credit booms, leading to soft landings. The contrast between Bad and Good (column 4) corroborates this trend, in the sense that the probability of a "bad" credit boom increases (decreases), relatively to "good" ones, when capital inflows and the credit-to-deposits ratio (interest rate spread) increase. In terms of odds-ratios, we observe that a percentage-point increase in TotCapInflows, Credit/Deposits and IRspread lead to a change of the odds by a factor of, respectively, 1.7366, 1.0598 and 0.9764 , ceteris paribus. ${ }^{15}$ In contrast, a higher economic growth and trade openness increase both probabilities equally, hence no significant difference is found in the estimated odds for the contrast Bad/Good associated with those variables. Moreover, a better current account stance contributes to decrease both probabilities (and to increase the probability of no boom), but in this case the higher liquidity it generates favours the occurrence of a soft landing. An overvaluation of the REER favours the build-up of a bad boom, while a more flexible exchange rate regime seems to drive credit booms to a soft landing.

Regarding the political conditionings, no clear evidence of an electoral cycle was found, but it becomes clear that right-wing governments are prone to avoid credit booms, especially those that are expected to end up in a banking crisis (relatively to good ones). These governments are known to have a higher propensity for inflation control, smaller deficits and a lower inclination to implement income redistribution policies, hence these policy preferences may contribute to reduce

\footnotetext{
${ }^{15}$ For example, for the case of the interest rate spread this means that when it increases one percentage point a bad credit boom becomes less likely than a good, as the odds-ratio is significantly lower than one. In the other two cases we have the expected opposite effect.
} 
the probability of credit booms evolving under the right's rule. Simultaneously, right-wing governments are also found to be less willing to implement redistribution policies that generally lead to the entrance into the credit market of people or projects that exhibit higher risk of default, thus reducing the danger of bad credit booms.

Regarding the number of government changes we get a surprising result. Even though political instability (i.e. more government changes) does not affect the appearance of credit booms, if they develop under such instability, there is a greater chance of them ending badly (see the respective marginal effect in column 3 and odds-ratio higher than one in column 4).

Our findings also show that "bad" credit booms are less likely to occur (relatively to "good" ones) under the watch of more independent Central Banks. ${ }^{16}$ As these institutions generally play an important role in monitoring the financial system and in preventing markets - and the overall economy - from overheating, they are at the centre of most discussions about how to prevent financial and banking crisis. Our results show that Central Banks can have an active role in controlling "bad" credit surges when they are allowed to establish the monetary policy independently from political pressures and electoral or ideological conveniences. Bad credit booms also seem to be (marginally) more likely when the country's monetary policy is in the hands of a regional monetary union. This might be related to contagion effects and a lower national control over the monetary policy.

\footnotetext{
${ }^{16}$ Results proved to be robust to different measures of Central Bank independence, namely to the use of the unweighted Central Bank independence index computed by Garriga (2016) and when resorting to the weighted and unweighted indices developed by Hicks and Bodea (see http://www.princeton.edu/ rhicks/data.html). These results are available upon request.
} 
The odds-ratios effects obtained with the multinomial logit are confirmed by a simple $\operatorname{logit}{ }^{17}$ (column 5) where only events of booms are considered, which means that we are contrasting the probability of "bad" against "good" credit booms.

The results from the estimation of the Sequential Logit are presented in columns 6 and 7. The simultaneous estimation of the two stages identified in the credit booms process not only confirms all previous results for the contrast between "bad" and "good" booms but also shows interesting findings for the contrast between credit booms and no credit booms. More specifically, credit booms (in general) are more likely with higher levels capital inflows, credit-to-deposits ratio, economic growth, trade openness, overvaluation of REER, political stability and under monetary unions. But they are less likely with a higher interest rate spread, better current account stance, right-wing governments, and with a higher degree of Central Bank independence.

From this sequential estimation, we can also emphasise that "bad" credit booms (in particular) are more likely, relatively to "good" credit booms, when capital inflows and credit-todeposits increase, REER is overvalued, and when there is political instability. This last result is even more striking when compared with the one we get in the first stage: while political instability prevents the occurrence of credit booms, when they happen they are more likely to end badly as consequence of that instability. However, "bad" ("good") credit booms have proven to be less (more) likely when the interest rate spread increases, the current account balance improves, with a more flexible exchange rate regime, with right-wing governments and with more independent Central Banks.

\footnotetext{
${ }^{17}$ In this case the dependent dummy variable takes the value of 1 when a "bad" credit boom is identified, and 0 for "good" ones.
} 
In sum, the results suggest that the quantity and price of credit, liquidity in the economy, economic growth, openness of the economy, political orientation and stability and an independent Central Bank are important factors to explain not only the occurrence of credit booms but also and most importantly - whether they end up in a systemic banking crisis or not. ${ }^{18}$

As an additional exercise, we split our sample in two groups: industrial countries (essentially OECD countries) and the others (essentially developing countries). The idea is to check whether or not these heterogeneous groups are differently affected by the economic, political and institutional determinants. The respective results are presented in Table 2. In general, the results from the Multinomial Logit are corroborated by the Sequential Logit.

\section{[Insert Table 2 around here]}

One important finding from this disaggregated analysis is that political instability (i.e. more government changes) favour the build-up of bad credit booms in developing countries. In this group, "bad" credit booms - and credit booms, in general (see column 9) are also less likely when right-wing parties are in office. More specifically, the odds-ratio coefficient is significantly lower than one in the contrast Bad/Good in both multinomial and sequential logit estimations. The political effects seem to be less relevant in the case of industrial countries, when we contrast "bad" with "good" booms.

A higher level of Central Bank independence reduces the likelihood of having a credit boom in industrial countries, in particular. However, all countries seem to benefit from a more independent monetary authority during the build-up phase since it helps to reduce the probability of a systemic banking crisis in the bust phase. On the contrary, credit booms have proven to be

\footnotetext{
${ }^{18}$ All the results reported in Table 1 are robust to other alternative and more restrictive thresholds (1.75 and 2.0) for the identification of credit booms (see Tables A.5 and A.6 in the Appendix).
} 
more likely in monetary unions, with a higher propensity to end badly especially in the group of industrial countries.

Regarding the economic variables, while "bad" credit booms seem to be mitigated by exchange rate flexibility, they tend to evolve over time with higher credit-to-deposits ratio, lower interest rate spread worse current account position, trade openness and exchange rate appreciation in both groups of countries. However, capital inflows and economic growth matter more for the build-up of "bad" booms in industrial countries than in developing ones. Additionally, the results from the Sequential Logit also show that: (i) economic growth, current account position and trade openness are important drivers of credit booms in both groups of countries; (ii) capital inflows matter more in the industrial countries; (iii) credit to deposits ratio and the interest rate spread play a major role in the credit boom dynamics in the group of developing countries.

In sum, while a better economic environment and Central Bank independence are essential for both groups of countries to avoid credit booms from ending up in systemic banking crises, the political factors seem to exert a stronger influence in developing countries.

\section{Conclusions}

This work extends the existing literature on credit booms by using a wider variety of econometric methodologies and by studying the particular impact of political factors and of Central Bank independence. The empirical analysis suggests the existence of a significant number of relevant economic differences between "good" and "bad" credit booms, contrary to previous empirical studies that have struggled to find ample evidence of economic differences between them. On the one hand, credit booms that are driven by high levels of capital inflows and/or by increases in the ratio of credit to deposits and those that are generally supported by lower interest 
rates tend to have an increased likelihood of ending up in a full blown banking crisis. On the other hand, a decrease in the inflows of capital and a higher relative price of credit seems to drive "healthier" credit booms leading to soft landings. In contrast, higher economic growth and trade openness appear to increase both probabilities equally.

The proposed existence of alternative, non-economic explanations for the behaviour of credit expansions proved to be true. We found strong statistical evidence that "bad" credit booms tend to be less frequent when right wing parties are in office, albeit the probability of having a credit boom is found to be lower during these periods. Also, credit booms developing under politically unstable environments seem to have a greater chance of ending badly. In contrast, this tendency for disaster decreases under the watch of more independent Central Banks. It seems that Central Banks can have an active role in controlling potentially "bad" credit surges provided they are allowed to establish the monetary policy independently from political pressures.

A further analysis of the results for the sub-samples of industrial and developing countries revealed that political factors are detrimental to explain the dynamics of credit booms towards a systemic banking crisis in developing countries, while a better economic environment and Central Bank independence are essential for both groups of countries to avoid that outcome. This further reinforces the idea that monetary authorities and the political environment play an important role in the unfolding of credit booms into a sweet or a sour ending. 


\section{References}

Agnello, L., Castro, V., Sousa, R., 2012. How does fiscal policy react to wealth composition and asset prices? Journal of Macroeconomics, 34(3), 874-890.

Agnello, L., and Sousa, R., 2013. Fiscal policy and asset prices. Bulletin of Economic Research, 65(2), 154-177.

Akyuz, Y., 2009. The Management of Capital Flows and Financial Vulnerability in Asia. Initiative for Policy Dialogue, Working Paper Series.

Alesina, A., 1987. Macroeconomic Policy in a Two-Party System as a Repeated Game. Quarterly Journal of Economics, 1023, 651-78.

Alesina, A., and Sachs, J., 1988. Political Parties and Business Cycle in the United States, 194884. Journal of Money, Credit, and Banking, 201, 63-82.

Arena, M., Bouza, S., Dabla-Norris, M. E., Gerling, M. K., and Njie, L. (2015). Credit Booms and Macroeconomic Dynamics: Stylized Facts and Lessons for Low-Income Countries. International Monetary Fund Working Paper 15/11.

Barajas, A., Dell'Ariccia, G., and Levchenko, A., 2009. Credit Booms: The Good, the Bad, and the Ugly. Unpublished manuscript, International Monetary Fund (Washington, DC).

Baron, M. and Xiong, W. Credit Expansion and Neglected Crash Risk. Quarterly Journal of Economics, 132(2), 713-764.

Boissay, F., Collard, F., and Smets, F., 2016. Booms and Banking Crises. Journal of Political Economy, 124(2), 489-538.

Borio, C., and Disyatat, P., 2011. Global imbalances and the financial crisis: Link or no link? BIS Working Papers No. 346.

Bradley D., Huber, E., Moller, S., Nielsen, F. and Stephens, J. 2003. Distribution and Redistribution in Postindustrial Democracies. World Politics 55(2): 193-228.

Broz, J. L. 2010. Partisan financial cycles. Politics in the New Hard Times: The Great Recession in Comparative Perspective. Ithaca, Cornell University Press.

Buis, M. L. 2008. The Consequences of Unobserved Heterogeneity in a Sequential Logit Model, http://home.fsw.vu.nl/m.buis/wp/unobserved het.pdf.

Buis, M., 2013. SEQLOGIT: Stata module to fit a sequential logit model, https://EconPapers.repec.org/RePEc:boc:bocode:s456843. 
Burnside, C., Eichenbaum, M. and Rebelo, S., 2016. Understanding Booms and Busts in Housing Markets. Journal of Political Economy, 124(4), 1088-1147.

Calderón, C. and Kubota, M., 2012.Gross inflows gone wild: gross capital inflows, credit booms and crises. World Bank Policy Research Working Paper No. 6270.

Calomiris, C. and Haber, S., 2014. Fragile by Design: The Political Origins of Banking Crises and Scarce Credit. Princeton University Press.

Canes-Wrone, B., and Park, J., 2014. Elections, Uncertainty and Irreversible Investment. British Journal of Political Science, 44(1), 83-106.

Chappell, H.W., Havrilesky, T.M., and McGregor, R.R., 1993. Partisan monetary policies: presidential influence through the power of appointment. Quarterly Journal of Economics, $108(1), 185-218$.

Claessens, S., Kose, M., and Terrones, M., 2011. Financial Cycles: What? How? When? IMF Working Paper No. 11/76.

Dell'Ariccia, G., Igan, D., Laeven, L., and Tong, H., 2016. Credit booms and macrofinancial stability. Economic Policy, 31(86), 299-355.

Elekdag, S., and Wu, Y., 2013. Rapid Credit Growth in Emerging Markets: Boon or Boom-Bust? Emerging Markets Finance and Trade, 49(5), 45-62.

Fernandez-Villaverde, J., Garicano, L. and Santos, T., 2013. Political Credit Cycles: The Case of the Eurozone. Journal of Economic Perspectives, 27(3), 145-66.

Franzese, R., 2002. Electoral and Partisan cycles in economic policies and outcomes. Annual Review of Political Science, 5, 369-421.

Garriga, A., 2016. Central Bank Independence in the World: A New Dataset. International Interactions, 42(5), 849-868.

Gourinchas, P-O, Valdes, R. and Landerretche, O., 2001. Lending Booms: Latin America and the World. Economia, 1(2), 47-99.

Gourinchas, P.-O. and Obstfeld, M., 2012. Stories of the twentieth century for the twenty-first. American Economic Journal: Macroeconomics, 4(1), 226-65.

Greene, W., 2012. Econometric Analysis, $7^{\text {th }}$ Ed., Prentice Hall, Upper Saddle River.

Havrilesky, T.M.,1988. Monetary policy signalling from the administration to the federal reserve. Journal of Money, Credit and Banking, 20, 82-101. 
Havrilesky, T.M., 1991. The frequency of monetary policy signalling from the administration to the federal reserve. Journal of Money, Credit and Banking, 23, 423-428.

Hibbs, D.A. Jr. 1977. Political Parties and Macroeconomic Policy. American Political Science Review, 71, 1467-87.

Ilzetzky, E., Reinhart, C., Rogoff, K., 2009. Exchange Rate Arrangements Entering the 21st Century: Which Anchor will Hold? Cambridge, MA, Harvard University, manuscript.

Iversen, T. and Soskice, D. 2006. Electoral Institutions and the Politics of Coalitions: Why Some Democracies Redistribute More than Others. American Political Science Review, 100(2), $165-81$.

Jens, C. E., 2017. Political uncertainty and investment: Causal evidence from U.S. gubernatorial elections. Journal of Financial Economics, 124(3), 563-579.

Laeven, L., and F. Valencia, 2008. Systemic banking crises: A new database. International Monetary Fund Working Paper 08/224.

Laeven, L., and F. Valencia, 2010. Resolution of banking crises: The good, the bad, and the ugly. International Monetary Fund Working Paper 10/146.

Laeven, L., and Valencia, F. (2012). Systemic banking crises database: An update. International Monetary Fund Working Paper 12/163.

Lohmann, S., 1998. Federalism and central bank independence: the politics of German monetary policy, 1957-9. World Politics 50, 401-446.

McCarty, N., Poole, K. and Rosenthal, H., 2013. Political Bubbles: Financial Crises and the Failure of American Democracy. Princeton University Press.

Mendoza, E., and Terrones, M., 2008. An Anatomy of Credit Booms: Evidence from Macro Aggregates and Micro Data. NBER Working Paper No. 14049.

Mendoza, E. and Terrones, M., 2012. An Anatomy of Credit Booms and their Demise. NBER Working Paper No. 18379.

Meng, C. and Gonzalez, R. L., 2017. Credit Booms in Developing Countries: Are They Different from Those in Advanced and Emerging Market Countries? Open Economies Review, 28(3), 547-579.

Nordhaus, W. 1975. The Political Business Cycle. Review of Economic Studies, XLII, 169-90. 
Paldam, M., 2004. Are Vote and Popularity Functions Economically Correct?, in C.K. Rowley \& F. Schneider (Eds.), The Encyclopedia of Public Choice (pp. 49-59). Netherlands: Kluwer Academic.

Popa, M., 2013. The Political Causes of Real Estate Bubbles. Unpublished manuscript.

Reinhart, C., Rogoff, K., 2004. The modern history of exchange rate arrangements: a reinterpretation. Quarterly Journal of Economics, 119(1), 1-48.

Reinhart, C., and Rogoff, K., 2009. The Aftermath of Financial Crises. The American Economic Review, 99(2), 466-472.

Rogoff, K., 1990. Equilibrium Political Budget Cycles. American Economic Review, 80(1), 2136.

Rogoff, K., and Sibert, A., 1988. Elections and Macroeconomic Policy Cycles. Review of Economic Studies, LV1, 1-16.

Sidaoui, J., Ramos-Francia, M., and Cuadra, G., 2011.Global liquidity, capital flows and challenges for policymakers: the Mexican experience. In: Capital flows, commodity price movements and foreign exchange intervention. Bank for International Settlements, BIS Papers No. 57, December.

Tornell, A. and Westermann, F., 2002. Boom-Bust Cycles in Middle Income Countries: Facts and Explanation. IMF Staff Papers, Vol. 49, Special Issue. 
Table 1. Determinants of "good" and "bad" credit booms

\begin{tabular}{|c|c|c|c|c|c|c|c|}
\hline \multirow[b]{2}{*}{ MgEffects } & \multicolumn{4}{|c|}{ Multinomial Logit } & \multirow{2}{*}{$\begin{array}{c}\text { Logit } \\
\begin{array}{c}\text { Bad/Good } \\
\text { (odds-ratio) } \\
(5)\end{array} \\
\end{array}$} & \multicolumn{2}{|c|}{ Sequential Logit } \\
\hline & $\begin{array}{c}\operatorname{Pr}(\mathrm{NoCB}) \\
\text { (mg.eff.) } \\
(1) \\
\end{array}$ & $\begin{array}{c}\operatorname{Pr}(\text { GoodCB }) \\
\text { (mg.eff.) } \\
(2)\end{array}$ & $\begin{array}{c}\operatorname{Pr}(\text { BadCB }) \\
\text { (mg.eff.) } \\
(3) \\
\end{array}$ & $\begin{array}{c}\text { Bad/Good } \\
\text { (odds-ratio) } \\
(4) \\
\end{array}$ & & $\begin{array}{c}\text { CBvsNoCB } \\
\text { (odds-ratio) } \\
(6) \\
\end{array}$ & $\begin{array}{c}\text { BadvsGood } \\
\text { (odds-ratio) } \\
(7)\end{array}$ \\
\hline TotCapInflows & $\begin{array}{c}0.0100 \\
(0.0113)\end{array}$ & $\begin{array}{c}-0.0314 * * \\
(0.0123)\end{array}$ & $\begin{array}{c}0.0214 * * * \\
(0.0038)\end{array}$ & $\begin{array}{c}1.7366 * * * \\
(0.2185)\end{array}$ & $\begin{array}{c}2.3421 * * * \\
(0.7456)\end{array}$ & $\begin{array}{c}1.1752 * * \\
(0.0911)\end{array}$ & $\begin{array}{c}2.4037 * * * \\
(0.7921)\end{array}$ \\
\hline Credit/Deposits & $\begin{array}{l}-0.0015 \\
(0.0012)\end{array}$ & $\begin{array}{l}-0.0017 \\
(0.0012)\end{array}$ & $\begin{array}{c}0.0032 * * * \\
(0.0005)\end{array}$ & $\begin{array}{c}1.0598 * * * \\
(0.0137)\end{array}$ & $\begin{array}{c}1.0602 * * * \\
(0.0149)\end{array}$ & $\begin{array}{c}1.1082 * * * \\
(0.0187)\end{array}$ & $\begin{array}{c}1.0629 * * * \\
(0.0148)\end{array}$ \\
\hline IRspread & $\begin{array}{l}-0.0004 \\
(0.0008)\end{array}$ & $\begin{array}{c}0.0015^{* *} \\
(0.0006)\end{array}$ & $\begin{array}{l}-0.0011^{*} \\
(0.0006)\end{array}$ & $\begin{array}{c}0.9764 * * \\
(0.0106)\end{array}$ & $\begin{array}{c}0.9460 * * * \\
(0.0140)\end{array}$ & $\begin{array}{c}0.9696^{* *} \\
(0.0143)\end{array}$ & $\begin{array}{c}0.9446 * * * \\
(0.0139)\end{array}$ \\
\hline RealGDPgr & $\begin{array}{c}-0.0132 * * * \\
(0.0028)\end{array}$ & $\begin{array}{c}0.0096 * * * \\
(0.0025)\end{array}$ & $\begin{array}{l}0.0036 * \\
(0.0019)\end{array}$ & $\begin{array}{c}0.9832 \\
(0.0336)\end{array}$ & $\begin{array}{c}1.0204 \\
(0.0422)\end{array}$ & $\begin{array}{c}1.1193 * * * \\
(0.0290)\end{array}$ & $\begin{array}{c}1.0509 \\
(0.0421)\end{array}$ \\
\hline Inflation & $\begin{array}{l}-0.0010 \\
(0.0010)\end{array}$ & $\begin{array}{c}0.0008 \\
(0.0008)\end{array}$ & $\begin{array}{c}0.0001 \\
(0.0008)\end{array}$ & $\begin{array}{c}0.9965 \\
(0.0132)\end{array}$ & $\begin{array}{c}0.9821 \\
(0.0200)\end{array}$ & $\begin{array}{c}1.0030 \\
(0.0114)\end{array}$ & $\begin{array}{c}0.9820 \\
(0.0200)\end{array}$ \\
\hline CurrAccount & $\begin{array}{c}0.0198 * * * \\
(0.0015)\end{array}$ & $\begin{array}{c}-0.0060 * * * \\
(0.0013)\end{array}$ & $\begin{array}{c}-0.0138 * * * \\
(0.0011)\end{array}$ & $\begin{array}{c}0.8629 * * * \\
(0.0170)\end{array}$ & $\begin{array}{c}0.8628 * * * \\
(0.0189)\end{array}$ & $\begin{array}{c}0.7820 * * * \\
(0.0160)\end{array}$ & $\begin{array}{c}0.8696 * * * \\
(0.0186)\end{array}$ \\
\hline Openness & $\begin{array}{c}-0.0847 * * * \\
(0.0191)\end{array}$ & $\begin{array}{c}0.0576 * * * \\
(0.0160)\end{array}$ & $\begin{array}{c}0.0271 * * \\
(0.0128)\end{array}$ & $\begin{array}{c}0.9245 \\
(0.2083)\end{array}$ & $\begin{array}{c}0.8831 \\
(0.2440)\end{array}$ & $\begin{array}{c}11.3252 * * * \\
(4.9180)\end{array}$ & $\begin{array}{c}0.8867 \\
(0.2477)\end{array}$ \\
\hline ApprecREER & $\begin{array}{c}-0.2686 * * \\
(0.1315)\end{array}$ & $\begin{array}{c}0.0358 \\
(0.1122)\end{array}$ & $\begin{array}{c}0.2328 * * \\
(0.0907)\end{array}$ & $\begin{array}{l}19.6854 * \\
(32.6911)\end{array}$ & $\begin{array}{l}11.0649 * * \\
(21.9646)\end{array}$ & $\begin{array}{l}9.6946 * * \\
(10.0959)\end{array}$ & $\begin{array}{c}15.0363 * * \\
(30.1049)\end{array}$ \\
\hline ExchRateFlex & $\begin{array}{l}-0.0116 \\
(0.0081)\end{array}$ & $\begin{array}{c}0.0155^{* *} \\
(0.0069)\end{array}$ & $\begin{array}{l}-0.0040 \\
(0.0056)\end{array}$ & $\begin{array}{l}0.8381 * \\
(0.0861)\end{array}$ & $\begin{array}{c}0.7471^{* *} \\
(0.0902)\end{array}$ & $\begin{array}{c}0.9374 \\
(0.0984)\end{array}$ & $\begin{array}{c}0.7575 * * \\
(0.0916)\end{array}$ \\
\hline YrBefElection & $\begin{array}{c}0.0044 \\
(0.0158)\end{array}$ & $\begin{array}{l}-0.0056 \\
(0.0135)\end{array}$ & $\begin{array}{c}0.0012 \\
(0.0106)\end{array}$ & $\begin{array}{c}1.0632 \\
(0.2051)\end{array}$ & $\begin{array}{c}1.1273 \\
(0.2363)\end{array}$ & $\begin{array}{c}0.8896 \\
(0.1097)\end{array}$ & $\begin{array}{c}1.1575 \\
(0.2421)\end{array}$ \\
\hline RightGov & $\begin{array}{c}0.0639 * * * \\
(0.0143)\end{array}$ & $\begin{array}{l}-0.0065 \\
(0.0120)\end{array}$ & $\begin{array}{c}-0.0574 * * * \\
(0.0103)\end{array}$ & $\begin{array}{c}0.4757 * * * \\
(0.0865)\end{array}$ & $\begin{array}{c}0.3956 * * * \\
(0.0829)\end{array}$ & $\begin{array}{c}0.6296 * * * \\
(0.0815)\end{array}$ & $\begin{array}{c}0.4097 * * * \\
(0.0852)\end{array}$ \\
\hline MajorityGov & $\begin{array}{c}0.0454 * * * \\
(0.0154)\end{array}$ & $\begin{array}{c}-0.0407 * * * \\
(0.0129)\end{array}$ & $\begin{array}{l}-0.0047 \\
(0.0106)\end{array}$ & $\begin{array}{c}1.2905 \\
(0.2448)\end{array}$ & $\begin{array}{l}1.5989 * * \\
(0.3535)\end{array}$ & $\begin{array}{c}1.1086 \\
(0.1566)\end{array}$ & $\begin{array}{l}1.4631 * \\
(0.3172)\end{array}$ \\
\hline NGovChanges & $\begin{array}{l}-0.0058 \\
(0.0102)\end{array}$ & $\begin{array}{l}-0.0118 \\
(0.0088)\end{array}$ & $\begin{array}{c}0.0176 * * * \\
(0.0067)\end{array}$ & $\begin{array}{c}1.4182 * * * \\
(0.1756)\end{array}$ & $\begin{array}{c}1.4755 * * * \\
(0.1907)\end{array}$ & $\begin{array}{c}0.8170 * * \\
(0.0749)\end{array}$ & $\begin{array}{c}1.4312 * * * \\
(0.1846)\end{array}$ \\
\hline$C B I$ & $\begin{array}{c}0.0163 \\
(0.0391)\end{array}$ & $\begin{array}{c}0.0191 \\
(0.0335)\end{array}$ & $\begin{array}{c}-0.0354 * * \\
(0.0166)\end{array}$ & $\begin{array}{l}0.5292^{*} \\
(0.2558)\end{array}$ & $\begin{array}{c}0.3640 * * \\
(0.1849)\end{array}$ & $\begin{array}{c}0.2515^{* *} \\
(0.1359)\end{array}$ & $\begin{array}{c}0.3340 * * \\
(0.1697)\end{array}$ \\
\hline$M U$ & $\begin{array}{c}-0.0546 * * \\
(0.0247)\end{array}$ & $\begin{array}{c}0.0227 \\
(0.0210) \\
\end{array}$ & $\begin{array}{l}0.0318 * \\
(0.0165) \\
\end{array}$ & $\begin{array}{c}1.2673 \\
(0.3824) \\
\end{array}$ & $\begin{array}{c}1.1656 \\
(0.3983) \\
\end{array}$ & $\begin{array}{c}4.1056 * * * \\
(1.3779)\end{array}$ & $\begin{array}{c}1.0728 \\
(0.3666) \\
\end{array}$ \\
\hline \#Observations & & 315 & & & 678 & & \\
\hline \#Countries & & 47 & & & 47 & & \\
\hline \#Episodes & & 64 & 24 & & $24 / 64$ & 88 & $24 / 64$ \\
\hline $\log L$ & & -181 & & & -360.3 & & \\
\hline SBIC & & 394 & & & 844.4 & & \\
\hline McFadden- $\mathrm{R}^{2}$ & & 0.1 & & & 0.211 & & \\
\hline
\end{tabular}

Notes: Estimations considering the Gourinchas et al. (2001) criteria with standard deviation threshold equal to 1.5. The number of credit boom episodes, by kind, is reported at the bottom of the table. The multinomial logit is estimated for 3 outcomes: no credit boom (NoCB); "good" credit boom (GoodCB); and "bad" credit boom (BadCB). The marginal effects for the respective probabilities are reported in columns 1-3. Column 4 presents the multinomial logit odds-ratio estimates for the contrast between "bad" and "good" credit booms. The odds ratios from the estimation of a simple logit model restricted to the subsample of credit booms to assess only the contrast between "bad" and "good" credit booms are reported in columns 5 and 6 . Columns 7 and 8 , present the estimated odds rations for the sequential logit model, where the first branch represents the contrast between credit booms and no credit booms and the second branch (or twig) is restricted to booms episodes to assess the effects for the contrast between "bad" and "good" credit booms. Decade dummies are used in all estimations to account for time effects. Fixed effects are accounted for only for the contrast between credit booms and no credit booms; they have to be excluded in the contrast between "bad" and "good" credit booms. In fact, Claessens et al. (2011, p.17) note that with a limited number of observations, spells or episodes per country, fixed effects may have to be ruled out. The Schwartz Bayesian Information Criterion, SBIC=$2 \log L+k \log (N)$, where $k$ is the number of regressors and $N$ is the number of observations. The McFadden- $\mathrm{R}^{2}=1-\operatorname{LogL} / \log L$, where $\log \mathrm{L}_{0}$ is the $\log$-likelihood of the model with only a constant term. 
Table 2. Industrial versus developing countries

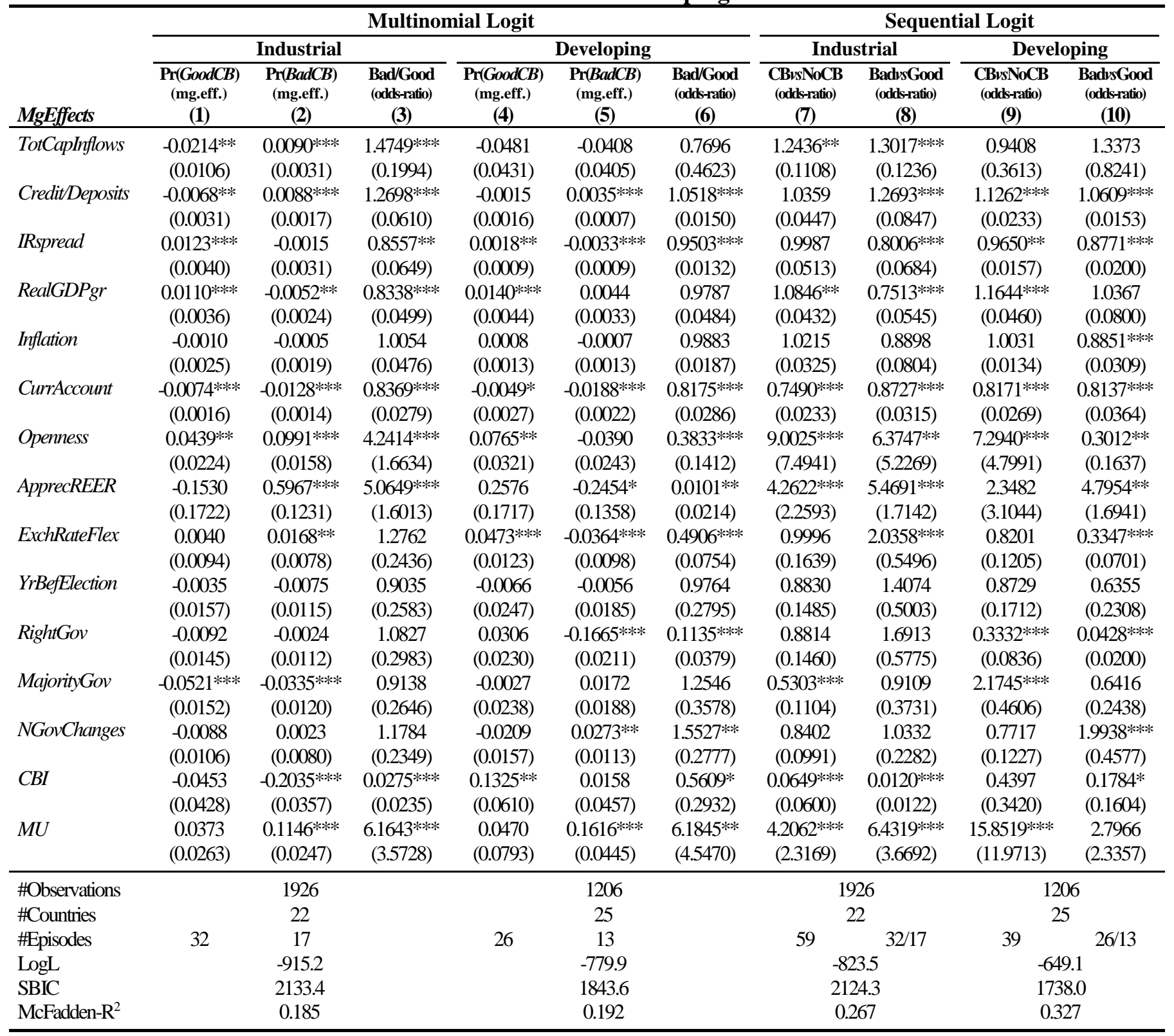

Notes: See Table 1. 


\section{Appendix}

Table A1. Credit booms dates and respective duration

\begin{tabular}{|c|c|c|c|c|c|c|c|}
\hline Country & Begin & End & Duration & Country & Begin & End & Duration \\
\hline Argentina & $1997 q 1$ & $1999 q 1$ & 9 & Japan & $1998 \mathrm{q} 2$ & $2001 \mathrm{q} 3$ & 14 \\
\hline Australia & $1989 q 1$ & $1991 \mathrm{q} 2$ & 10 & Korea Republic & $2002 q 2$ & $2004 q 1$ & 9 \\
\hline Australia & $2007 q 4$ & $2009 q 2$ & 7 & Korea Republic & $2008 \mathrm{q} 1$ & $2009 q 2$ & 6 \\
\hline Austria & $2005 q 2$ & $2006 q 3$ & 6 & Latvia & $1997 q 2$ & 1999q1 & 8 \\
\hline Bolivia & $1990 \mathrm{q} 2$ & $1995 q 1$ & 20 & Latvia & $2000 \mathrm{q} 3$ & $2008 \mathrm{q} 2$ & 32 \\
\hline Bolivia & $1996 \mathrm{q} 4$ & $1998 \mathrm{q} 4$ & 9 & Latvia & $2009 q 3$ & $2010 \mathrm{q} 3$ & 5 \\
\hline Brazil & $2006 \mathrm{q} 3$ & $2008 \mathrm{q} 4$ & 10 & Luxembourg & $2005 q 2$ & $2006 \mathrm{q} 4$ & 7 \\
\hline Bulgaria & $2001 \mathrm{q} 4$ & $2009 q 3$ & 32 & Luxembourg & $2007 q 4$ & $2008 \mathrm{q} 4$ & 5 \\
\hline Canada & $1981 \mathrm{q} 2$ & $1982 q 3$ & 6 & Malta & $2000 q 2$ & $2002 q 1$ & 8 \\
\hline Canada & $2001 \mathrm{q} 4$ & $2003 q 2$ & 7 & Malta & $2008 \mathrm{q} 2$ & $2009 q 2$ & 5 \\
\hline Canada & $2006 \mathrm{q} 3$ & $2006 q 4$ & 2 & Mexico & $1989 q 1$ & $1995 q 3$ & 27 \\
\hline Chile & $2007 q 3$ & $2009 q 1$ & 7 & Netherlands & $1996 \mathrm{q} 1$ & 1998q1 & 9 \\
\hline Colombia & $1997 q 3$ & $1999 q 2$ & 8 & Norway & $1984 q 4$ & 1991q2 & 27 \\
\hline Colombia & $2006 q 3$ & $2009 q 1$ & 11 & Norway & $1997 \mathrm{q} 3$ & $1998 \mathrm{q} 4$ & 6 \\
\hline Costa Rica & $1998 \mathrm{q} 1$ & $2001 \mathrm{q} 1$ & 13 & Norway & $2006 q 2$ & $2006 q 4$ & 3 \\
\hline Costa Rica & $2007 q 1$ & $2009 q 3$ & 8 & Paraguay & $2001 \mathrm{q} 2$ & $2003 q 1$ & 8 \\
\hline Croatia & $1997 q 4$ & $1998 \mathrm{q} 4$ & 5 & Paraguay & $2007 q 3$ & $2009 q 2$ & 8 \\
\hline Croatia & $2001 \mathrm{q} 1$ & $2003 q 3$ & 11 & Paraguay & $2010 q 2$ & $2010 \mathrm{q} 4$ & 3 \\
\hline Cyprus & $2000 q 1$ & $2001 q 4$ & 8 & Peru & $1995 \mathrm{q} 3$ & $1999 \mathrm{q} 1$ & 15 \\
\hline Cyprus & $2007 q 1$ & $2008 \mathrm{q} 2$ & 6 & Philippines & $1983 q 2$ & $1984 q 3$ & 6 \\
\hline Czech Republic & $1996 \mathrm{q} 2$ & $1998 \mathrm{q} 3$ & 10 & Philippines & $1993 q 2$ & $1998 \mathrm{q} 3$ & 22 \\
\hline Czech Republic & $2005 q 2$ & $2008 \mathrm{q} 3$ & 14 & Poland & $2006 \mathrm{q} 3$ & $2009 q 2$ & 12 \\
\hline Denmark & $1986 \mathrm{q} 3$ & $1986 \mathrm{q} 4$ & 2 & Portugal & $1997 q 1$ & $2003 q 1$ & 25 \\
\hline Denmark & $1987 q 4$ & $1990 \mathrm{q} 4$ & 13 & Portugal & $2007 q 4$ & $2009 q 1$ & 6 \\
\hline Denmark & $2000 q 3$ & $2000 q 4$ & 2 & Romania & $1998 \mathrm{q} 3$ & $1999 q 1$ & 3 \\
\hline Ecuador & $1993 q 3$ & $1995 q 4$ & 10 & Romania & $2001 \mathrm{q} 4$ & $2009 q 2$ & 31 \\
\hline Ecuador & $1997 q 3$ & $1998 \mathrm{q} 4$ & 6 & Russian Federation & $1998 \mathrm{q} 3$ & $2002 q 2$ & 16 \\
\hline Ecuador & $2001 \mathrm{q} 1$ & $2002 q 2$ & 6 & Russian Federation & $2006 q 1$ & $2009 q 2$ & 14 \\
\hline Estonia & $1996 \mathrm{q} 2$ & $1998 \mathrm{q} 2$ & 9 & Slovak Republic & $1996 \mathrm{q} 2$ & 1998q2 & 9 \\
\hline Estonia & $2005 q 3$ & $2009 q 1$ & 15 & Slovenia & $2004 q 1$ & $2009 q 2$ & 22 \\
\hline Finland & $1989 q 1$ & $1993 q 1$ & 17 & South Africa & $2001 \mathrm{q} 2$ & $2002 q 1$ & 4 \\
\hline Finland & $2007 q 4$ & $2008 \mathrm{q} 4$ & 5 & South Africa & $2006 q 1$ & $2009 q 1$ & 13 \\
\hline France & $1978 \mathrm{q} 1$ & $1979 q 4$ & 8 & Spain & $2006 q 4$ & $2009 q 2$ & 11 \\
\hline France & $2007 q 3$ & $2008 \mathrm{q} 4$ & 6 & Sweden & 2001q1 & $2003 q 3$ & 11 \\
\hline Germany & $2000 q 1$ & $2001 q 4$ & 8 & Thailand & $1995 \mathrm{q} 4$ & $1999 q 2$ & 15 \\
\hline Germany & $2008 \mathrm{q} 4$ & $2009 q 3$ & 4 & Thailand & $2010 q 2$ & $2010 \mathrm{q} 3$ & 2 \\
\hline Greece & $2007 q 3$ & $2008 \mathrm{q} 4$ & 7 & Ukraine & $1999 q 3$ & $2004 q 3$ & 20 \\
\hline Greece & $2010 q 2$ & $2011 q 1$ & 4 & Ukraine & $2005 q 3$ & $2009 q 3$ & 17 \\
\hline Hungary & $2000 q 1$ & 2001q1 & 5 & United Kingdom & $2007 q 4$ & $2009 q 1$ & 6 \\
\hline Hungary & $2003 q 2$ & $2004 q 3$ & 6 & United States & $1978 \mathrm{q} 3$ & 1980q1 & 7 \\
\hline Hungary & $2007 q 4$ & $2009 q 1$ & 6 & United States & $1988 \mathrm{q} 4$ & $1990 \mathrm{q} 4$ & 9 \\
\hline Iceland & $1997 q 4$ & $2001 q 2$ & 15 & United States & $2007 q 2$ & $2009 q 1$ & 8 \\
\hline Iceland & $2004 q 1$ & $2008 \mathrm{q} 3$ & 19 & & & & \\
\hline Italy & $1991 \mathrm{q} 4$ & $1993 q 4$ & 9 & & & & \\
\hline Italy & $1999 q 1$ & $2001 q 4$ & 12 & & & & \\
\hline Italy & $2010 \mathrm{q} 2$ & $2011 \mathrm{q} 1$ & 4 & Average duration & & & 10.4 \\
\hline
\end{tabular}

Notes: This list only reports those countries and events of credit booms that are used in the estimations Credit booms identified using Gourinchas et al. (2001) and Barajas et al. (2009) criterion. 


\section{Table A2. Description of variables and respective sources}

\begin{tabular}{|c|c|c|}
\hline Variable & Description & Source \\
\hline CreditBoom & $\begin{array}{l}\text { Defined as an episode where the deviation of the real bank credit to the } \\
\text { private sector, as a percentage of real GDP, from a country-specific } \\
\text { trend in country } i \text { at period } t \text { (with the trend being calculated up to that } \\
\text { period } t \text { ) exceeds a determined threshold. A credit boom takes place if } \\
\text { the ratio of private credit to GDP meets the following condition: the } \\
\text { deviation of this ratio from its estimated trend is greater than } 1.5 \text { times } \\
\text { its standard deviation or the year-on-year growth rate of private credit } \\
\text { to GDP exceeds } 20 \text { percent. }\end{array}$ & Own calculations. \\
\hline TotCapInflows & $\begin{array}{l}\text { Total gross capital inflows as percentage of GDP (CapInflows). } \\
\text { Includes information from three main components: foreign direct } \\
\text { investment, portfolio investment and other investment liability } \\
\text { inflows. }\end{array}$ & $\begin{array}{l}\text { IMF's Balance of Payments } \\
\text { Statistics (BOP). GDP: World } \\
\text { Development Indicators (WDI). }\end{array}$ \\
\hline Credit/Deposits & $\begin{array}{l}\text { Ratio of private credit to bank deposits (Credit/Deposits). Deposits are } \\
\text { measured as the sum of demand and time deposits. }\end{array}$ & $\begin{array}{l}\text { IMF-International } \quad \text { Financial } \\
\text { Statistics (IFS), lines } 24 \text { and } 25 .\end{array}$ \\
\hline IRspread & $\begin{array}{l}\text { Difference between the average lending rate and the deposit rate, in } \\
\text { percentage. }\end{array}$ & IMF - IFS \\
\hline RealGDPgr & year-over-year GDP growth rate. & Datastream and national sources \\
\hline Inflation & year-over-year percentage change of the consumer price index (CPI) & IMF - IFS \\
\hline CurrAccount & Current account balance as percentage of GDP. & WDI \\
\hline Openness & exports plus imports over GDP. & IMF - IFS \\
\hline ApprecREER & $\begin{array}{l}\text { Overvaluation of the real effective exchange rate. An overvaluation is } \\
\text { measured as the deviation of the REER index from its HP-filtered trend }\end{array}$ & IMF - IFS \\
\hline ExchRateFlex & $\begin{array}{l}\text { Exchange rate flexibility. Set by the coarse classification of the } \\
\text { exchange rate regime. The coarse index varies between } 1 \text { and } 6 \text { : higher } \\
\text { values indicate a more flexible exchange rate arrangement. }\end{array}$ & $\begin{array}{l}\text { Reinhart and Rogoff (2004), and } \\
\text { Ilzetzky, Reinhart and Rogoff } \\
\text { (2009). }\end{array}$ \\
\hline YrBefElection* & Dummy equal to 1 in the 4 quarters before the election. & $\begin{array}{l}\text { Database of Political Institutions } \\
2015 \text { (DPI). }\end{array}$ \\
\hline RightGov* & Dummy equal to 1 for right-wing governments. & DPI \\
\hline MajorityGov* & Dummy equal to 1 in presence of majority governments. & DPI \\
\hline NGovChanges & $\begin{array}{l}\text { Number of government changes (due to elections or not) over the } \\
\text { previous five years. }\end{array}$ & DPI \\
\hline$C B I$ & Cukierman-Webb-Neyapti index. & Garriga (2016) \\
\hline$M U$ & $\begin{array}{l}\text { Dummy equal to } 1 \text { when the country's monetary policy is in the hands } \\
\text { of a regional monetary union. }\end{array}$ & National sources. \\
\hline
\end{tabular}


Table A3: Descriptive statistics for the episodes and duration of credit booms

\begin{tabular}{lccccc}
\hline & \#Spells & Mean & St.Dev. & Min. & Max. \\
\hline All countries (67) & 220 & 8.04 & 5.82 & 1 & 32 \\
OECD countries (28) & 76 & 8.28 & 5.31 & 1 & 27 \\
Non-OECD countries (39) & 144 & 7.91 & 6.08 & 1 & 32 \\
"Bad" credit booms & 55 & 10.62 & 6.74 & 2 & 32 \\
"Good" credit booms & 165 & 7.18 & 5.22 & 1 & 32 \\
\hline
\end{tabular}

Notes: This table reports the number of episodes/spells (\#Spells), the mean duration (Mean), the standard deviation (St.Dev.), the minimum (Min.) and the maximum (Max.) duration for credit booms. The data are quarterly and comprises 67 countries over the period 1975q1-2016q4. Credit booms are identified using the works of Gourinchas et al. (2001) and Barajas et al. (2009). A credit boom takes place when the deviation of the ratio of credit to GDP from its trend exceeds 1.5 times of its standard deviation or the (year-on-year) growth in the credit-GDP ratio exceeds 20 percent.

Table A4. Descriptive statistics for the variables

\begin{tabular}{|c|c|c|c|c|c|}
\hline Variable & Obs. & Mean & Std. Dev. & Min. & Max. \\
\hline CreditBoom & 3935 & 0.24 & 0.43 & 0 & 1 \\
\hline TotCapInflows & 3883 & 0.19 & 1.05 & -7.96 & 19.22 \\
\hline Credit/Deposits & 3935 & 5.96 & 7.47 & 0.28 & 105.88 \\
\hline Irspread & 3933 & 6.27 & 8.12 & -17.12 & 121.00 \\
\hline RealGDPgr & 3934 & 3.13 & 3.20 & -14.81 & 14.04 \\
\hline Inflation & 3935 & 5.90 & 7.43 & -3.82 & 101.55 \\
\hline CurrAccount & 3935 & -1.26 & 5.31 & -25.55 & 17.47 \\
\hline Openness & 3935 & 0.73 & 0.41 & 0.16 & 3.58 \\
\hline ApprecREER & 3888 & 0.00 & 0.06 & -0.65 & 0.41 \\
\hline ExchRateFlex & 3935 & 2.36 & 1.13 & 1 & 6 \\
\hline ElectionQtr & 3935 & 0.07 & 0.25 & 0 & 1 \\
\hline RightGov & 3237 & 0.45 & 0.50 & 0 & 1 \\
\hline CentreGov & 3237 & 0.12 & 0.33 & 0 & 1 \\
\hline LeftGov & 3237 & 0.42 & 0.49 & 0 & 1 \\
\hline MajorityGov & 3760 & 0.69 & 0.46 & 0 & 1 \\
\hline NGovChanges & 3863 & 1.51 & 0.77 & 0 & 5 \\
\hline$C B I$ & 3932 & 0.59 & 0.24 & 0.13 & 0.90 \\
\hline$M U$ & 3935 & 0.13 & 0.34 & 0 & 1 \\
\hline BankCrisis & 3934 & 0.05 & 0.21 & 0 & 1 \\
\hline
\end{tabular}

Notes: This table reports the number of observations for each variable, their mean (Mean), standard deviation (Std.Dev.), minimum (Min.) and maximum (Max.) for the maximum number of countries that could be used in the estimations (47 countries) over the period 1975q1-2016q4. 
Table A5. Robustness checks with threshold equal to 1.75

\begin{tabular}{|c|c|c|c|c|c|c|c|}
\hline \multirow[b]{2}{*}{ MgEffects } & \multicolumn{4}{|c|}{ Multinomial Logit } & \multirow{2}{*}{$\begin{array}{c}\text { Logit } \\
\begin{array}{c}\text { Bad/Good } \\
\text { (odds-ratio) } \\
(5)\end{array} \\
\end{array}$} & \multicolumn{2}{|c|}{ Sequential Logit } \\
\hline & $\begin{array}{c}\operatorname{Pr}(N o C B) \\
\text { (mg.eff.) } \\
(1) \\
\end{array}$ & $\begin{array}{c}\operatorname{Pr}(\text { GoodCB }) \\
\text { (mg.eff.) } \\
(2) \\
\end{array}$ & $\begin{array}{c}\operatorname{Pr}(\text { BadCB }) \\
\text { (mg.eff.) } \\
(3) \\
\end{array}$ & $\begin{array}{c}\begin{array}{c}\text { Bad/Good } \\
\text { (odds-ratio) } \\
(4)\end{array} \\
\end{array}$ & & $\begin{array}{c}\text { CBvsNoCB } \\
\text { (odds-ratio) } \\
(6) \\
\end{array}$ & $\begin{array}{c}\text { BadvsGood } \\
\text { (odds-ratio) } \\
(7) \\
\end{array}$ \\
\hline TotCapInflows & $\begin{array}{c}0.0070 \\
(0.0130)\end{array}$ & $\begin{array}{c}-0.0315^{* *} \\
(0.0141)\end{array}$ & $\begin{array}{c}0.0245 * * * \\
(0.0039)\end{array}$ & $\begin{array}{c}1.9292 * * * \\
(0.2996)\end{array}$ & $\begin{array}{c}3.0164 * * * \\
(1.2712)\end{array}$ & $\begin{array}{l}1.1509 * \\
(0.0852)\end{array}$ & $\begin{array}{c}3.1612 * * * \\
(1.3617)\end{array}$ \\
\hline Credit/Deposits & $\begin{array}{l}-0.0013 \\
(0.0012)\end{array}$ & $\begin{array}{l}-0.0018 \\
(0.0012)\end{array}$ & $\begin{array}{c}0.0031 * * * \\
(0.0005)\end{array}$ & $\begin{array}{c}1.0644 * * * \\
(0.0145)\end{array}$ & $\begin{array}{c}1.0767 * * * \\
(0.0184)\end{array}$ & $\begin{array}{c}1.1036 * * * \\
(0.0188)\end{array}$ & $\begin{array}{c}1.0780 * * * \\
(0.0178)\end{array}$ \\
\hline IRspread & $\begin{array}{l}-0.0009 \\
(0.0007)\end{array}$ & $\begin{array}{c}0.0016 * * * \\
(0.0006)\end{array}$ & $\begin{array}{l}-0.0007 \\
(0.0006)\end{array}$ & $\begin{array}{c}0.9758 * * \\
(0.0107)\end{array}$ & $\begin{array}{c}0.9319 * * * \\
(0.0149)\end{array}$ & $\begin{array}{c}0.9776 \\
(0.0143)\end{array}$ & $\begin{array}{c}0.9310 * * * \\
(0.0147)\end{array}$ \\
\hline RealGDPgr & $\begin{array}{c}-0.0146 * * * \\
(0.0027)\end{array}$ & $\begin{array}{c}0.0094 * * * \\
(0.0024)\end{array}$ & $\begin{array}{c}0.0052 * * * \\
(0.0018)\end{array}$ & $\begin{array}{c}1.0042 \\
(0.0360)\end{array}$ & $\begin{array}{c}1.0531 \\
(0.0488)\end{array}$ & $\begin{array}{c}1.1324 * * * \\
(0.0302)\end{array}$ & $\begin{array}{l}1.0878^{*} \\
(0.0487)\end{array}$ \\
\hline Inflation & $\begin{array}{l}-0.0007 \\
(0.0010)\end{array}$ & $\begin{array}{c}0.0006 \\
(0.0008)\end{array}$ & $\begin{array}{c}0.0001 \\
(0.0007)\end{array}$ & $\begin{array}{c}0.9978 \\
(0.0140)\end{array}$ & $\begin{array}{c}1.0011 \\
(0.0195)\end{array}$ & $\begin{array}{c}0.9988 \\
(0.0117)\end{array}$ & $\begin{array}{c}1.0001 \\
(0.0197)\end{array}$ \\
\hline CurrAccount & $\begin{array}{c}0.0192 * * * \\
(0.0015)\end{array}$ & $\begin{array}{c}-0.0062 * * * \\
(0.0012)\end{array}$ & $\begin{array}{c}-0.0130 * * * \\
(0.0011)\end{array}$ & $\begin{array}{c}0.8617 * * * \\
(0.0182)\end{array}$ & $\begin{array}{c}0.8509 * * * \\
(0.0213)\end{array}$ & $\begin{array}{c}0.7858 * * * \\
(0.0165)\end{array}$ & $\begin{array}{c}0.8588 * * * \\
(0.0210)\end{array}$ \\
\hline Openness & $\begin{array}{l}-0.0377 * \\
(0.0195)\end{array}$ & $\begin{array}{c}0.0206 \\
(0.0166)\end{array}$ & $\begin{array}{c}0.0171 \\
(0.0128)\end{array}$ & $\begin{array}{c}1.0818 \\
(0.2742)\end{array}$ & $\begin{array}{c}0.9285 \\
(0.3068)\end{array}$ & $\begin{array}{c}3.1526 * * \\
(1.5408)\end{array}$ & $\begin{array}{c}0.9114 \\
(0.3018)\end{array}$ \\
\hline ApprecREER & $\begin{array}{l}-0.1513 \\
(0.1268)\end{array}$ & $\begin{array}{l}-0.0094 \\
(0.1068)\end{array}$ & $\begin{array}{l}0.1607 * \\
(0.0860)\end{array}$ & $\begin{array}{c}12.2596 \\
(21.1079)\end{array}$ & $\begin{array}{l}9.3434 * * \\
(11.1677)\end{array}$ & $\begin{array}{c}3.0914 \\
(3.2674)\end{array}$ & $\begin{array}{c}10.9581 * * \\
(10.9296)\end{array}$ \\
\hline ExchRateFlex & $\begin{array}{l}-0.0025 \\
(0.0079)\end{array}$ & $\begin{array}{c}0.0084 \\
(0.0068)\end{array}$ & $\begin{array}{l}-0.0059 \\
(0.0054)\end{array}$ & $\begin{array}{c}0.8470 \\
(0.0915)\end{array}$ & $\begin{array}{c}0.7218^{* *} \\
(0.0924)\end{array}$ & $\begin{array}{c}0.8718 \\
(0.0939)\end{array}$ & $\begin{array}{c}0.7317 * * \\
(0.0938)\end{array}$ \\
\hline YrBefElection & $\begin{array}{l}-0.0041 \\
(0.0153)\end{array}$ & $\begin{array}{l}-0.0001 \\
(0.0129)\end{array}$ & $\begin{array}{c}0.0042 \\
(0.0102)\end{array}$ & $\begin{array}{c}1.0679 \\
(0.2163)\end{array}$ & $\begin{array}{c}1.0452 \\
(0.2382)\end{array}$ & $\begin{array}{c}0.9810 \\
(0.1239)\end{array}$ & $\begin{array}{c}1.0716 \\
(0.2441)\end{array}$ \\
\hline RightGov & $\begin{array}{c}0.0666^{* * *} * \\
(0.0140)\end{array}$ & $\begin{array}{l}-0.0071 \\
(0.0116)\end{array}$ & $\begin{array}{c}-0.0595 * * * \\
(0.0101)\end{array}$ & $\begin{array}{c}0.4293 * * * \\
(0.0834)\end{array}$ & $\begin{array}{c}0.2547 * * * \\
(0.0633)\end{array}$ & $\begin{array}{c}0.5432 * * * \\
(0.0733)\end{array}$ & $\begin{array}{c}0.2692 * * * \\
(0.0661)\end{array}$ \\
\hline MajorityGov & $\begin{array}{c}0.0402 * * * \\
(0.0148)\end{array}$ & $\begin{array}{c}-0.0301 * * \\
(0.0124)\end{array}$ & $\begin{array}{l}-0.0101 \\
(0.0100)\end{array}$ & $\begin{array}{c}1.1135 \\
(0.2193)\end{array}$ & $\begin{array}{l}1.8022 * * \\
(0.4556)\end{array}$ & $\begin{array}{c}1.0655 \\
(0.1541)\end{array}$ & $\begin{array}{l}1.6039 * \\
(0.3952)\end{array}$ \\
\hline NGovChanges & $\begin{array}{l}-0.0084 \\
(0.0100)\end{array}$ & $\begin{array}{l}-0.0148 * \\
(0.0087)\end{array}$ & $\begin{array}{c}0.0232 * * * \\
(0.0063)\end{array}$ & $\begin{array}{c}1.6405^{* * *} * \\
(0.2123)\end{array}$ & $\begin{array}{c}1.7499 * * * \\
(0.2488)\end{array}$ & $\begin{array}{c}0.8925 \\
(0.0835)\end{array}$ & $\begin{array}{c}1.7008 * * * \\
(0.2412)\end{array}$ \\
\hline$C B I$ & $\begin{array}{c}0.0486 \\
(0.0376)\end{array}$ & $\begin{array}{c}0.0011 \\
(0.0318)\end{array}$ & $\begin{array}{c}-0.0497 * * \\
(0.0252)\end{array}$ & $\begin{array}{c}0.4581 \\
(0.2293)\end{array}$ & $\begin{array}{l}0.3831 * \\
(0.2093)\end{array}$ & $\begin{array}{c}0.1713 * * * \\
(0.0944)\end{array}$ & $\begin{array}{c}0.3378 * * \\
(0.1845)\end{array}$ \\
\hline$M U$ & $\begin{array}{l}-0.0079 \\
(0.0246) \\
\end{array}$ & $\begin{array}{c}0.0002 \\
(0.0205)\end{array}$ & $\begin{array}{c}0.0077 \\
(0.0170)\end{array}$ & $\begin{array}{c}1.0838 \\
(0.3621)\end{array}$ & $\begin{array}{c}0.8052 \\
(0.3093)\end{array}$ & $\begin{array}{c}2.6150 * * * \\
(0.8958)\end{array}$ & $\begin{array}{c}0.7318 \\
(0.2815)\end{array}$ \\
\hline \#Observations & & \multicolumn{2}{|c|}{3157} & & 620 & \multicolumn{2}{|c|}{3157} \\
\hline \#Countries & & \multicolumn{2}{|c|}{45} & & 45 & \multicolumn{2}{|c|}{45} \\
\hline \#Episodes & & 55 & 19 & & $19 / 55$ & 74 & $19 / 55$ \\
\hline $\log L$ & \multicolumn{4}{|c|}{-1697.5} & -308.0 & \multicolumn{2}{|c|}{-1492.5} \\
\hline SBIC & \multicolumn{4}{|c|}{3717.3} & 738.2 & \multicolumn{2}{|c|}{3670.0} \\
\hline McFadden- $\mathrm{R}^{2}$ & \multicolumn{4}{|c|}{0.153} & 0.264 & \multicolumn{2}{|c|}{0.255} \\
\hline
\end{tabular}


Table A6. Robustness checks with threshold equal to 2.0

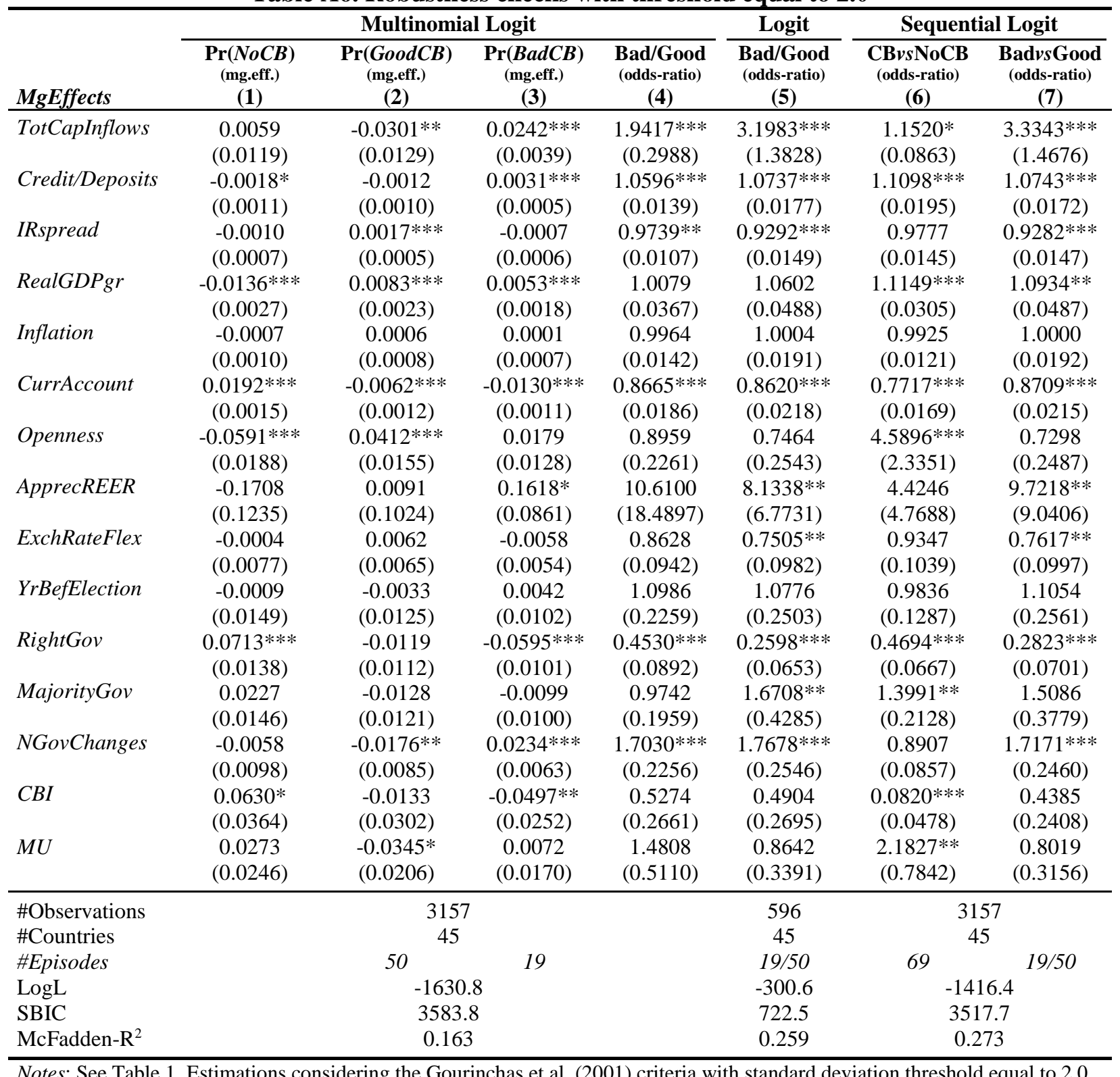

Notes: See Table 1. Estimations considering the Gourinchas et al. (2001) criteria with standard deviation threshold equal to 2.0. 
CeBer Working Papers

(Available on-line at www.uc.pt/go/ceber)

2018-14 Why are credit booms sometimes sweet and sometimes sour? - Vítor Castro \& Rodrigo Martins

2018-13 Copula-based Tests for Nonclassical Measurement Error - The Case of Fractional Random Variables - José M. R. Murteira

2018-12 Differentiated Impact of Spread Determinants by Personal Loan Category: Evidence from the Brazilian Banking Sector - José Valente, Mário Augusto \& José Murteira

2018-11 The Effect of Family Ownership, Control and Management on Corporate Debt Structure - Evidence from Panel Fractional Data - Mário Augusto, José Murteira \& António Pedro Pinto

2018-10 Predictability of stock returns and dividend growth using dividend yields: An international approach - Ana Sofia Monteiro, Hélder Sebastião \& Nuno Silva

2018-09 Political and institutional determinants of credit booms - Vítor Castro \& Rodrigo Martins

2018-08 An Aggregate View of Portuguese Exports and Competitiveness - Pedro Bação, António Portugal Duarte \& Diogo Viveiros

2018-07 The Cycle of recycling and sustainable development. Evidence from the OECD Countries - Pedro André Cerqueira, Elias Soukiazis \& Sara Proença

2018-06 Information Transmission Between Cryptocurrencies: Does Bitcoin Rule the Cryptocurrency World? - Pedro Bação, António Portugal Duarte, Hélder Sebastião \& Srdjan Redzepagic

2018-05 Endogenous Growth and Entropy - Tiago Neves Sequeira, Pedro Mazeda Gil \& Óscar Afonso

2018-04 Determinants of overall and sectoral entrepreneurship: evidence from Portugal Gonçalo Brás \& Elias Soukiazis

2018-03 Young and healthy but reluctant to donate blood: An empirical study on attitudes and motivations of university students - Tiago Henriques \& Carlota Quintal

2018-02 The Iberian electricity market: Price dynamics and risk premium in an illiquid market Márcio Ferreira \& Hélder Sebastião

2018-01 Health Investment and Long run Macroeconomic Performance: a quantile regression approach - Francisca Silva, Marta Simões \& João Sousa Andrade 
2017-12 Deflation in the Euro Zone: Overview and Empirical Analysis - Pedro Bação \& António Portugal Duarte

2017-11 Fiscal Consolidation Programs and Income Inequality - Pedro Brinca, Miguel H. Ferreira, Francesco Franco, Hans A. Holter \& Laurence Malafry

2017-10 The interconnections between Renewable Energy, Economic Development and Environmental Pollution. A simultaneous equation system approach - Elias Soukiazis, Sara Proença \& Pedro André Cerqueira

2017-09 The Renminbi: A Warrior for Competitiveness? - Pedro Bação, António Portugal Duarte \& Matheus Santos

2017-08 Le Portugal et l'Euro - João Sousa Andrade

2017-07 The Effect of Public Debt on Growth in Multiple Regimes in the Presence of Long-Memory and Non-Stationary Debt Series - Irina Syssoyeva-Masson \& João Sousa Andrade

2017-06 The Blank and the Null: An examination of non-conventional voting choices - Rodrigo Martins

2017-05 Where is the information on USD/Bitcoins hourly price movements? - Helder Sebastião, António Portugal Duarte \& Gabriel Guerreiro

2017-04 The response of non-price competitiveness and productivity due to changes in passed income gaps. Evidence from the OECD countries - Pedro André Cerqueira, Micaela Antunes \& Elias Soukiazis

2017-03 Dutch Disease in Central and Eastern European Countries - João Sousa Andrade \& António Portugal Duarte

2017-02 On the gains of using high frequency data and higher moments in Portfolio Selection- Rui Pedro Brito, Hélder Sebastião \& Pedro Godinho

2017-01 Growth adjustments through non-price competitiveness and productivity. A cumulative causation approach- Elias Soukiazis, Micaela Antunes \& Pedro André Cerqueira

A série CeBER Working Papers foi iniciada em 2017. 